\title{
Extraadrenal Steroid 21-Hydroxylation Is Not Mediated by P450c21
}

\author{
Synthia H. Mellon ${ }^{\star \ddagger}$ and Walter L. Miller ${ }^{\star 5}$ \\ Departments of ${ }^{*}$ Obstetrics, Gynecology and Reproductive Sciences and ${ }^{\S}$ Pediatrics, and the ${ }^{\ddagger}$ Metabolic Research Unit, \\ University of California, San Francisco, California 94143
}

\begin{abstract}
The 21-hydroxylation of progesterone to deoxycorticosterone (DOC) and of 17-hydroxyprogesterone to 11-deoxycortisol in the human adrenal cortex is mediated by a single enzyme termed P450c21. Extraadrenal tissues can clear circulating progesterone and progesterone sulfate by 21 -hydroxylation to DOC and DOC-sulfate. It has previously been established that such extraadrenal 21-hydroxylase activity is widely distributed in adult and fetal tissues, but it has not been known if extraadrenal 21-hydroxylation is mediated by the same P450c21 enzyme found in the adrenal. We examined human RNA from fetal adrenal, liver, kidney, lung, brain, heart, skin, spleen, testis, and placenta by solution hybridization to human P450c21 probes transcribed from cloned human P450c21 cDNA, followed by nuclease protection and acrylamide gel electrophoresis. No P450c21 mRNA was detectable in any extraadrenal tissue. The sensitivity of the assay would have detected P450c21 mRNA at $0.01 \%$ of its abundance in the human fetal adrenal. Similar experiments in rats showed no P450c21 mRNA in brain, heart, kidney, liver, lung, testis, ovary, or uterus. These results clearly demonstrate that one or more enzymes other than the classical adrenal 21-hydroxylase are responsible for human and rat extraadrenal 21-hydroxylation.
\end{abstract}

\section{Introduction}

The pathways of adrenal and gonadal steroid hormone synthesis were traditionally examined by studying the kinetics of precursor-product relationships, leading to the conclusion that each steroidal conversion required a separate and specific enzyme or enzymes (1). However, recent advances in enzyme purification leading to the cloning of cDNAs and genes for these enzymes have now greatly modified this view by showing that each steroidogenic enzyme can perform multiple steps (2). A subtle corollary of this conclusion is that any single steroidogenic step need not necessarily be mediated by only one enzyme. In this report we prove this corollary by demonstrating that extraadrenal tissues having 21-hydroxylase activity lack the mRNA for the adrenal 21-hydroxylase, P450c21.

Steroid 21-hydroxylation has been studied in considerable detail, in part because congenital adrenal hyperplasia due to

Address all correspondence to Dr. Synthia H. Mellon, Dept. of Ob/ Gyn and Reproductive Sciences, HSW-1475, University of California, San Francisco, CA 94143-0546. 1989.

Received for publication 8 June 1989 and in revised form 17 July

J. Clin. Invest.

(c) The American Society for Clinical Investigation, Inc.

0021-9738/89/11/1497/06 \$2.00

Volume 84, November 1989, 1497-1502 defective adrenal 21-hydroxylation affects $\sim 1$ of 10,000 persons. A single specific form of cytochrome P450, termed P450c21, mediates the 21-hydroxylation of both progesterone and 17-hydroxyprogesterone $(17 \mathrm{OHP})^{1}$ to deoxycorticosterone (DOC) and 11-deoxycortisol, respectively (3). The cDNA and genes for $\mathrm{P} 450 \mathrm{c} 21$ have been cloned and characterized from several species (reviewed in reference 2) and the disorders of the human 21-hydroxylase gene locus associated with congenital adrenal hyperplasia have been studied in detail by numerous groups (4).

Steroid 21-hydroxylation also occurs in a wide variety of human adult and fetal extraadrenal tissues, which take up circulating progesterone and convert it to DOC or DOC sulfate (reviewed in reference 5). The nature of the enzyme(s) mediating this extraadrenal 21-hydroxylase activity is unknown. Some studies suggest that P450c21 might be the extraadrenal 21-hydroxylase, but others do not. Authentic P450c21 mRNA was found in mouse liver by molecular cloning (6), in bovine testis by hybridization of RNA to cloned cDNA followed by $S_{1}$ nuclease digestion (7), and in a human Leydig cell adenoma by Northern blotting (8). By contrast, rabbit hepatic 21-hydroxylation is mediated by $\mathrm{P} 450-1$, which is structurally unrelated to P450c21 (9), and P450c21 mRNA was not detected in human fetal tissues by a relatively insensitive Northern blotting procedure that had difficulty detecting adrenal P450c21 mRNA (10). Extraadrenal 21-hydroxylation persisted in one patient with adrenal hyperplasia due to 21-hydroxylase deficiency, but this patient had an incomplete enzymatic defect and retained the ability to 21-hydroxylate progesterone to DOC in her adrenal (11). Thus, the nature of the enzyme(s) mediating extraadrenal 21-hydroxylation and the presence or absence of P450c21 mRNA in extraadrenal human tissues have been unclear. To determine if human fetal extraadrenal tissues contained enough P450c21 mRNA to account for their high levels of 21-hydroxylase activity (12) we examined RNA from such tissues by solution hybridization and nuclease protection.

\section{Methods}

RNA preparation. Human fetal tissues were obtained from elective early second trimester cervical dilatation and evacuation under approved protocols of the Department of Obstetrics, Gynecology, and Reproductive Sciences at the University of California, San Francisco. Fetal tissues were frozen in liquid $\mathrm{N}_{2}$ and used to prepare RNA as described (13), except that ultracentrifugation was done in a TLS-55 rotor (Beckman Instruments, Inc., Palo Alto, CA) at 50,000 rpm for 4 $\mathrm{h}$, and each tube contained a $0.5-\mathrm{ml}$ cushion of $5.7 \mathrm{M} \mathrm{CsCl}$ and $2.0 \mathrm{ml}$ of tissue lysis solution. Rat tissues were stored frozen in liquid $\mathrm{N}_{2}$ and used for RNA preparation by the $\mathrm{LiCl}$ precipitation procedure (14).

1. Abbreviations used in this paper: DOC, deoxycorticosterone; 17OHP, 17-hydroxyprogesterone. 

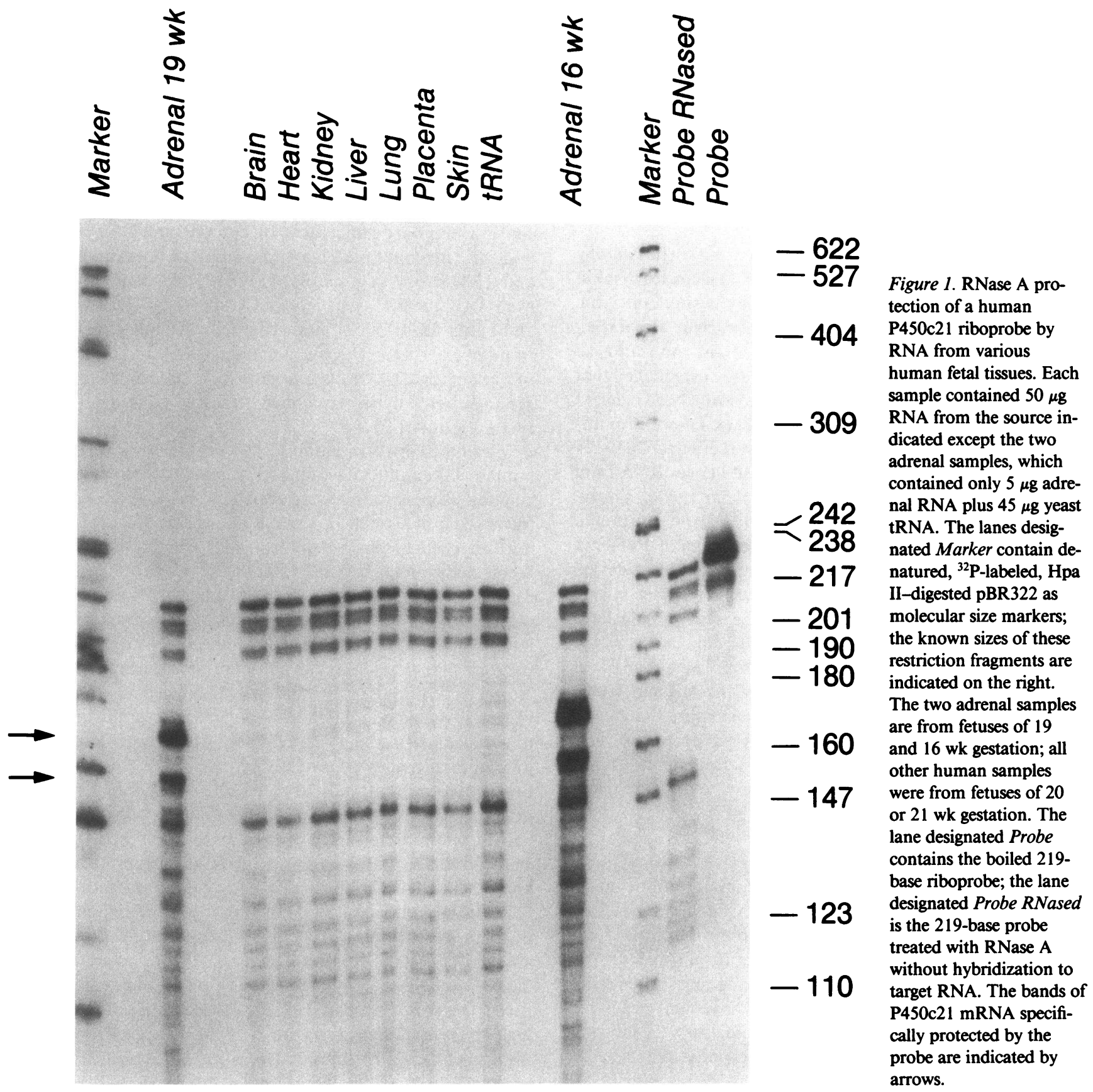

Riboprobes. For experiments with rat RNA the 1,223-bp human P450c21 cDNA fragment from phac21-1 (15) was cloned into the Eco RI site of pGEM-3 (Promega Biotec, Madison, WI). The recombinant plasmid was linearized with Hind III and RNA was transcribed with T7 RNA polymerase in the presence of $\left[{ }^{32} \mathrm{P}\right] U T P$ as described (16). For experiments with human RNA a 376-bp Eco RI/Nar I fragment of phac21-1 was cloned into Eco RI/Cla I-digested pBluescript KS (Stratagene, La Jolla, CA). This probe is encoded by exons 7-9 of the P450c21 gene and hence lies outside the region in exon 10 where a second gene is encoded on the nontranscribed strand of the P450c21 gene (17). The recombinant plasmid was linearized with Sma I, and RNA was transcribed with T3 RNA polymerase. The Sma I digestion cuts the plasmid within the 376-bp fragment of P450c21 cDNA; transcription from the $\mathrm{T} 3$ promoter yields a 219 -base RNA containing 46 bases of vector sequences and 173 bases of P450c21 sequences. Labeled RNA probes were purified by DNase treatment, phenol/chloroform extraction, and two precipitations with ethanol.
Hybridizations. 50- $\mu \mathrm{g}$ samples of human RNA or 100- $\mu \mathrm{g}$ samples of rat RNA were mixed with $\sim 10^{6} \mathrm{cpm}$ of ${ }^{32} \mathrm{P}$-riboprobe $(\sim 1 \mathrm{ng}$ RNA) in $80 \%$ deionized formamide, $400 \mathrm{mM} \mathrm{NaCl}, 40 \mathrm{mM}$ Pipes (pH 6.4), $1 \mathrm{mM}$ EDTA, boiled $5 \mathrm{~min}$, and incubated $16 \mathrm{~h}$ at $37^{\circ} \mathrm{C}$ for rat RNA, or at $42^{\circ} \mathrm{C}$ for human RNA. Samples were diluted 10-fold with $10 \mathrm{mM}$ Tris- $\mathrm{HCl}$ (pH 7.9), $300 \mathrm{mM} \mathrm{NaCl}$ and 5 mM EDTA containing RNase A, $1 \mu \mathrm{g} / \mathrm{ml}$ for rat RNA samples or $20 \mu \mathrm{g} / \mathrm{ml}$ for human RNA samples, both for $1 \mathrm{~h}$ at $37^{\circ} \mathrm{C}$. Samples were treated with a final concentration of $0.25 \mathrm{mg} / \mathrm{ml}$ proteinase $\mathrm{K}$ and $0.5 \% \mathrm{NaDodSO}_{4}$ for 15 min at $37^{\circ} \mathrm{C}$, extracted with phenol and chloroform, precipitated with ethanol, and displayed by electrophoresis on $0.4 \mathrm{~mm} 5$ or $6 \%$ polyacrylamide gels.

$S_{I}$ nuclease protection experiments. Hybridization of 30- $\mu \mathrm{g}$ RNA samples to a single-stranded DNA probe and digestion with $S_{1}$ nuclease were done exactly as described previously (7). The DNA probe was transcribed with Klenow polymerase from an M13mp10 clone containing a 387-base Pst I fragment of phac21-1 encoding amino acids 


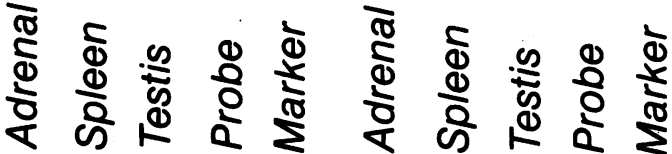

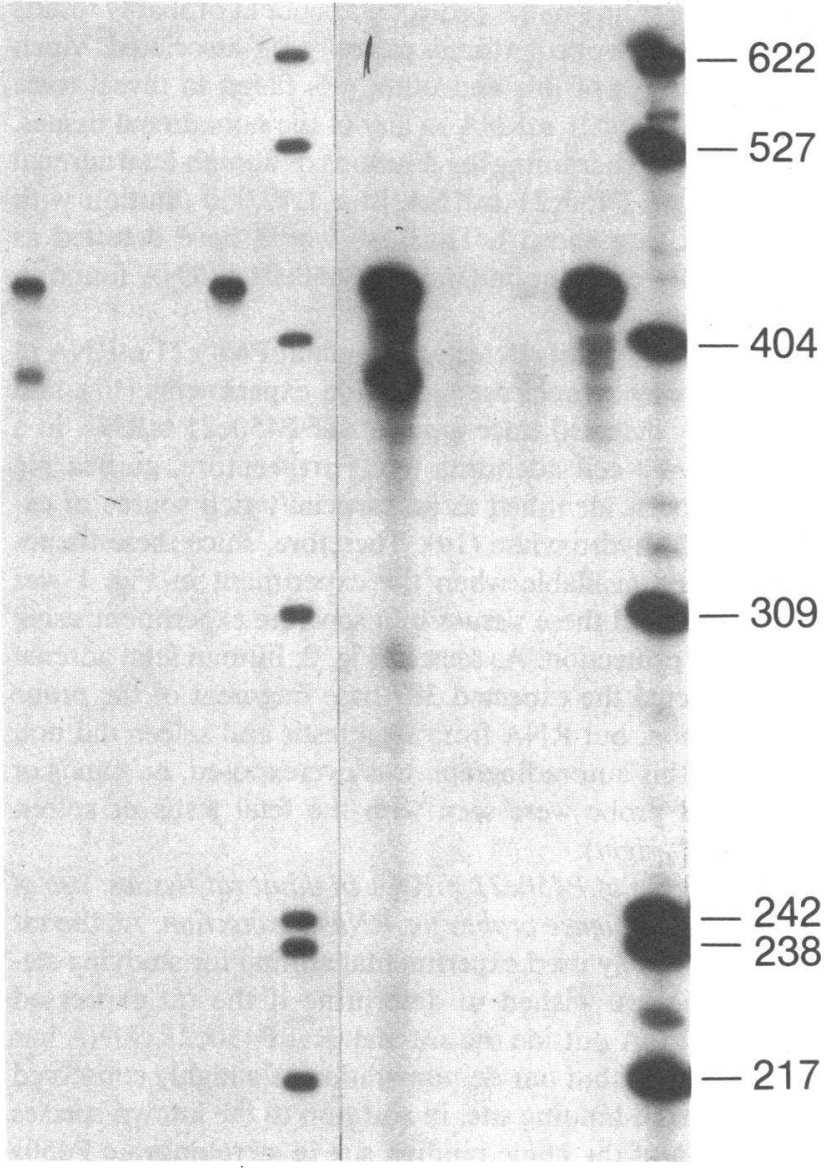

Figure 2. $\mathrm{S}_{1}$ nuclease protection of human $\mathrm{P} 450 \mathrm{c} 21$ single-stranded DNA probe by human RNAs. The lane designations are as in Fig. 1; each reaction used $30 \mu \mathrm{g}$ of human fetal RNA from the tissue indicated. The right half of the figure represents a 2-wk autoradiographic exposure, the left represents a 1-d exposure. Not all of the unhybridized, single-stranded probe was digested in the reaction containing adrenal RNA, accounting for the two bands in this lane.

318-446 of P450c21 (15). The double-stranded DNA, with only one labeled strand, was cut out with Pst I and boiled to yield a 431-base probe consisting of 387 bases of P450c21 sequences and 44 bases of vector sequences.

$R$ Nase $V_{\text {l }}$ treatment. $5 \mu \mathrm{g}$ of rat adrenal RNA mixed with $45 \mu \mathrm{g}$ of yeast tRNA were hybridized to the 1,275-base human $\mathrm{P} 450 \mathrm{c} 21$ probe as described above. RNase $A$ at $1 \mu \mathrm{g} / \mathrm{ml}$ and $R N a s e ~ V_{1} 0-3,500 \mathrm{mU} / \mathrm{ml}$ were added in $20 \mathrm{mM}$ Tris $\mathrm{HCl}$ (pH 7.2), $200 \mathrm{mM} \mathrm{NaCl}$ and $10 \mathrm{mM}$ $\mathrm{MgCl}_{2}$ (18). Samples were then treated with proteinase $\mathrm{K}$ and $\mathrm{Na}$ DodSO $_{4}$ and analyzed as described above.

\section{Results}

Distribution of P450c21 mRNA in human fetal tissues. Because extraadrenal 21-hydroxylase activity is greater in human fetal tissues than in adult tissues (12), we examined the same fetal tissues studied by Casey et al. (12). We prepared a 219-bp
${ }^{32} \mathrm{P}$-labeled riboprobe using a fragment of human $\mathrm{P} 450 \mathrm{c} 21$ cDNA. The probe was hybridized to various RNA samples, then digested with ribonuclease $A$, and the products were analyzed by PAGE and autoradiography. As seen in Fig. 1 (right lane), the 219-base probe had an electrophoretic mobility approximately equal to the 217-bp Hpa II fragment of pBR322 (DNA and RNA migrate slightly differently). The other bands seen in this lane represent self-aggregation of the probe. This is shown in the lane where the single-stranded RNA probe was digested with RNase A, which digests single- but not doublestranded RNA. The prominent bands seen at $\sim 216,208,198$, and $150 \mathrm{bp}$ indicate self-association of the probe yielding RNase A-resistant double-stranded structures; these bands of self-associated probe can be seen in all other lanes as well. When the probe is hybridized to $50 \mu \mathrm{g}$ of RNA from human
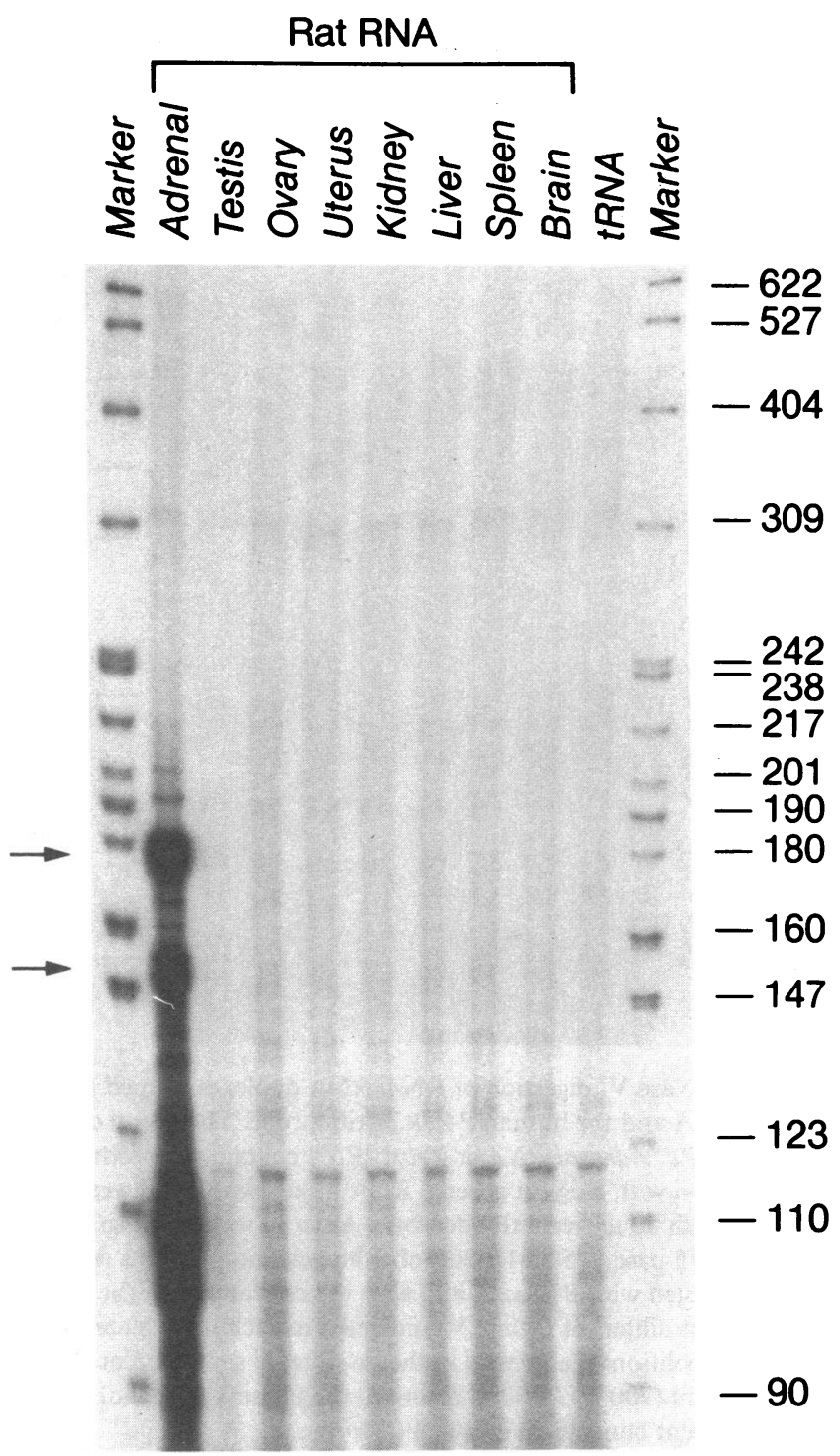

Figure 3. RNase A protection of a 1,275-base human P450c21 riboprobe by RNA from various rat tissues. Lane designations are as in Fig. 1. Each sample contained $100 \mu \mathrm{g}$ RNA from the source indicated, except the adrenal sample, which contained $10 \mu \mathrm{g}$ of rat adrenal RNA and $90 \mu \mathrm{g}$ of yeast tRNA. The major protected bands of rat P450c21 mRNA are indicated by the two arrows (left). 


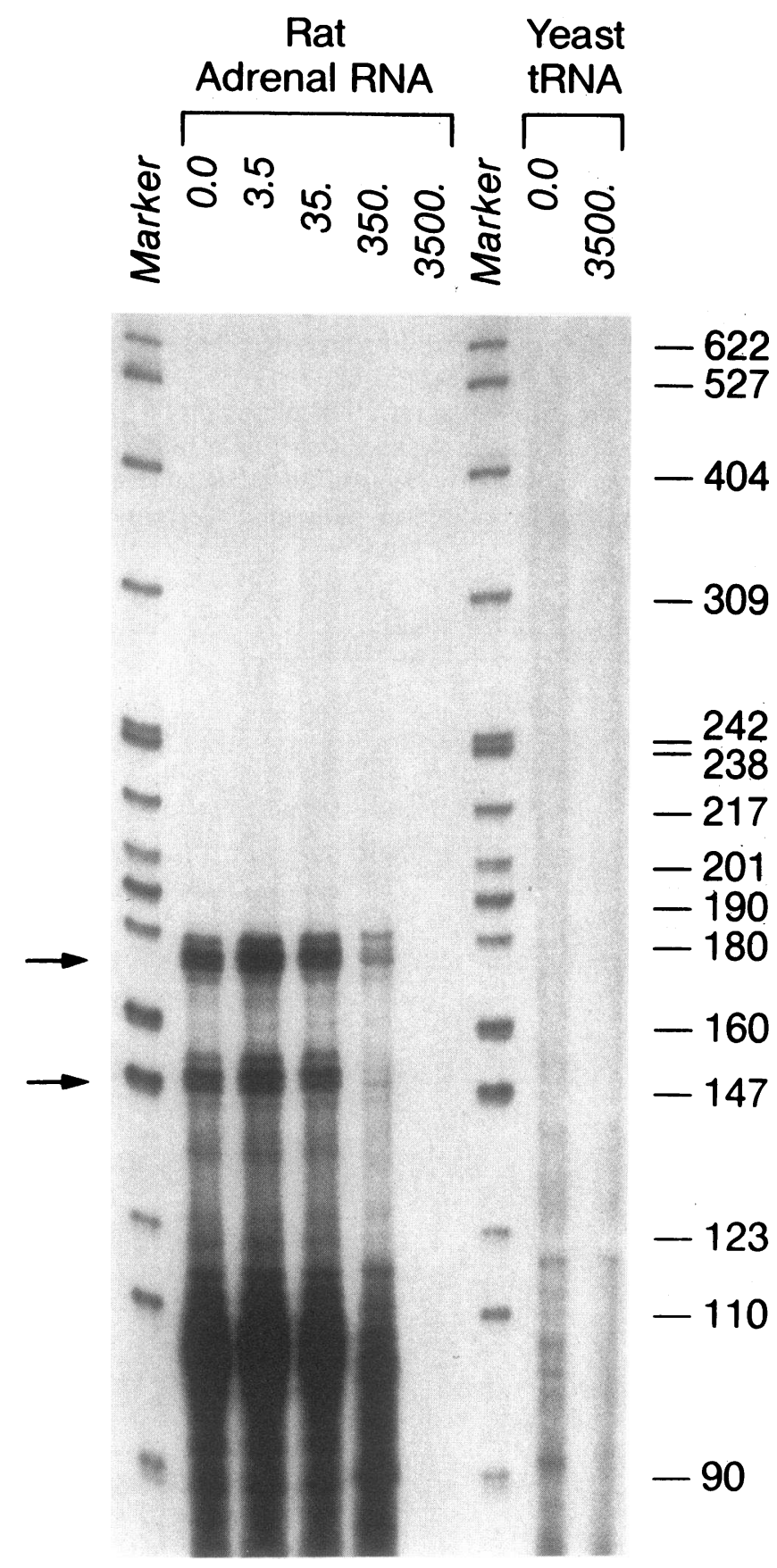

Figure 4. RNase $\mathrm{V}_{1}$ digestion of RNA/RNA duplexes formed by rat adrenal RNA and the human P450c21 riboprobe. The group of lanes designated Rat Adrenal RNA or Yeast $t R N A$ contain the products of hybridization with $5 \mu \mathrm{g}$ rat adrenal RNA mixed with $45 \mu \mathrm{g}$ yeast tRNA or with $50 \mu \mathrm{g}$ yeast tRNA alone. After hybridization to the human 1,275-base $\mathrm{P} 450 \mathrm{c} 21$ riboprobe the reaction products were doubly digested with RNase $A$ and with the concentration (in milliunits per milliliter) of $R$ Nase $V_{1}$ indicated in each lane. Note the complete abolition of all bands in the rat adrenal sample treated with $3,500 \mathrm{mU} / \mathrm{ml}\left(700 \mathrm{mU} / 200 \mu \mathrm{l}\right.$ reaction) of $\mathrm{RNase} \mathrm{V}_{1}$, including the two prominent bands seen in Fig. 3 (arrows).

fetal brain, heart, kidney, liver, lung, placenta, and skin, or to $50 \mu \mathrm{g}$ of yeast tRNA, no bands resistant to RNase A were seen other than those due to self-association of the probe seen in the control lanes. By contrast, $5 \mu \mathrm{g}$ of human fetal adrenal RNA diluted with $45 \mu \mathrm{g}$ of yeast tRNA protected two prominent bands of 170-173 and 159 bases. As the 219-base probe contained 46 bases of vector sequences and 173 bases of P450c21 sequences, the 170-173-base band was of the predicted and expected size. The smaller protected fragment probably results from protection by probe that is partially self-associated. Much longer exposures of this and other gels failed to reveal trace amounts of P450c21 mRNA in any of the nonadrenal tissues. An experiment examining log dilutions of human fetal adrenal RNA detected P450c21 mRNA in a 1:10,000 dilution with yeast tRNA (not shown). Thus, we would have detected as little as $0.01 \%$ of the abundance of P450c21 mRNA found in the adrenal.

We have previously detected abundant P450c21 mRNA in bovine testis by $S_{1}$ nuclease protection experiments (17), and also recently detected trace amounts of P450c21 mRNA in a human Leydig cell adenoma (8). Furthermore, guinea pig spleen has been identified as an especially rich source of extraadrenal 21-hydroxylase (19). Therefore, since these tissues had not been available when the experiment in Fig. 1 was done, we studied these tissues in a separate experiment using $S_{1}$ nuclease protection. As seen in Fig. 2, human fetal adrenal RNA protected the expected 387-base fragment of the probe from digestion, but RNA from fetal testis and spleen did not; even when this autoradiograph was overexposed, no bands of $\mathrm{S}_{1}$-protected probe were seen with the fetal testis or spleen RNA (Fig. 2, right).

Distribution of P450c21 mRNA in adult rat tissues: use of heterologous sequence probes for RNase protection. As the rat is the most widely used experimental animal for studying steroidogenesis, we wished to determine if the rat expressed P450c21 mRNA outside the adrenal. Rat P450c21 cDNA has not been cloned, but our demonstration of a highly conserved putative steroid-binding site, in addition to the known species conservation of the heme-binding site in steroidogenic P450s (20), suggested that some regions of the rat and human P450c21 sequences would be sufficiently similar (i.e., nearly identical) to yield hybrids resistant to RNase $A$. In the absence of a known rat $P 450 \mathrm{c} 21$ sequence, the number, length, and location of the regions of high similarity between rat and human P450c 21 could not be determined. Therefore, we used a much longer human riboprobe for these heterologous sequence hybridizations than the 173 bases of human P450c21 used in Fig. 1. As shown in Fig. 3, when the 1,275-base riboprobe containing 1,223 bases of human P450c21 sequences was hybridized to $100 \mu \mathrm{g}$ of RNA from rat testis, ovary, uterus, kidney, liver, spleen, or brain, or to $100 \mu \mathrm{g}$ of yeast tRNA, no significant protection of the probe from digestion with RNase A occurred. By contrast, $10 \mu \mathrm{g}$ of rat adrenal RNA diluted with $90 \mu \mathrm{g}$ of yeast tRNA readily protected two prominent bands of 178-179 and 147-148 bases, indicating the human probe could readily detect rat $P 450 \mathrm{c} 21 \mathrm{mRNA}$. Thus, extraadrenal rat tissues, like extraadrenal human tissues, contain no more than $0.01 \%$ of the abundance of P450c $21 \mathrm{mRNA}$ found in the adrenal.

Because the use of heterologous sequence probes for RNase A protection experiments is a new technique, we wished to prove that the protected bands seen in Fig. 3 were truly due to specific RNA/RNA hybridization and did not represent an artifact (e.g., contamination of the adrenal RNA with genomic 
DNA). We first hybridized rat adrenal RNA to the human riboprobe and digested the mixture with RNase $\mathrm{A}$, as was done in Fig. 3. Aliquots of this material were then digested with increasing amounts of RNase $V_{1}$, which only digests doublestranded RNA but not single-stranded RNA, RNA/DNA hybrids, or DNA. As seen in Fig. 4, all of the radioactivity protected by rat adrenal RNA from digestion with RNase A could be digested with RNase $V_{1}$. By contrast, the minimal amount of radioactivity that remained after RNase A treatment of probe hybridized to yeast tRNA remained after $R$ Nase $V_{1}$ digestion. This indicates that the background seen in the hybridization with yeast tRNA or with the rat nonadrenal tissues was simply due to small amounts of undigested single-stranded fragments of the probe, or probe hybridizing to trace amounts of template DNA. Thus, the use of riboprobes from heterologous species for RNase A protection experiments can yield highly specific and exquisitely sensitive detection of certain species of mRNA.

\section{Discussion}

Although extraadrenal 21-hydroxylation has been found in all mammals examined for this activity, its biochemical basis and role have been unknown (5). In the human fetus extraadrenal 21-hydroxylase activity is widely distributed and may exceed the activity found in the fetal adrenal (12). The studies we have presented show that these tissues can contain no more than $0.01 \%$ of the P450c21 mRNA found in the fetal adrenal. Thus, even if there is some P450c21 mRNA in these extraadrenal tissues at concentrations below the sensitivity of our assay, it is clear that the encoded P450c21 protein cannot account for the abundant 21-hydroxylase activity found in human fetal extraadrenal tissues.

Some patients who have been described having severe, salt-wasting 21-hydroxylase deficiency nonetheless recover the capacity to make enough mineralocorticoids to avoid a saltlosing crisis in adult life $(21,22)$. While this encouraged speculation that the enzymes mediating the 21-hydroxylation of progesterone to deoxycorticosterone and of 17OHP to 11deoxycortisol were different (22), the demonstration that there is only one P450c21 involved in adrenal 21-hydroxylation has ruled this out (2-4). By contrast, we would propose that chronically elevated circulating concentrations of progesterone and 17OHP, possibly in concert with other factors associated with hypovolemia (e.g., increased concentrations of renin and angiotensin II) might induce the extraadrenal 21-hydroxylase(s). Mineralocorticoids are required at 100 -fold lower concentrations than glucocorticoids. Thus, even if extraadrenal 21-hydroxylation is much less efficient than adrenal P450c21, a small induction of extraadrenal 21-hydroxylation might have a significant effect on mineral metabolism even in the face of continued evidence of glucocorticoid insufficiency. This hypothesis fits both the clinical observations and the known molecular biology of 21-hydroxylase. It must now be tested directly by determining the molecular identity of extraadrenal 21-hydroxylase(s).

\section{Acknowledgments}

We thank Dr. Bon-chu Chung for the experiment in Fig. 2 and Carol Dahlstrom for typing the manuscript.
This work was supported by National Institutes of Health grants HD-22013 (to Dr. Mellon) and DK-37922 (to Dr. Miller), University of California AIDS grant 86SF024, and March of Dimes grant 6-396 (to Dr. Miller), and by a grant from the W. M. Keck Foundation to the Department of Obstetrics, Gynecology, and Reproductive Sciences.

\section{References}

1. Lieberman, S., N. J. Greenfield, and A. Wolfson. 1984. A heuristic proposal for understanding steroidogenic processes. Endocr. Rev. 5:128-148.

2. Miller, W. L. 1988. Molecular biology of steroid hormone synthesis. Endocr. Rev. 9:295-318.

3. Kominani, S., H. Ochi, T. Kobayashi, and S. Takemori. 1980. Studies on the steroid hydroxylation system in adrenal cortex microsomes: purification and characterization of cytochrome $\mathrm{P} 450$ specific for steroid 21-hydroxylation. J. Biol. Chem. 255:3386-3394.

4. Miller, W. L., and Y. Morel. 1989. Molecular genetics of 21-hydroxylase deficiency. Annu. Rev. Genet. 23:371-393.

5. Casey, M. L., and P. C. MacDonald. 1982. Extraadrenal formation of a mineralocorticosteroid: Deoxycorticosterone and deoxycorticosterone sulfate biosynthesis and metabolism. Endocr. Rev. 3:396403.

6. Amor, M., M. Tosi, C. Duponchel, M. Steinmetz, and T. Meo. 1985. Liver cDNA probes disclose two cytochrome P450 genes duplicated in tandem with the complement C4 loci of the mouse $\mathrm{H}-2 \mathrm{~S}$ region. Proc. Natl. Acad. Sci. USA. 82:4453-4457.

7. Chung, B., K. J. Matteson, and W. L. Miller. 1986. Structure of a bovine gene for P450c21 (steroid 21-hydroxylase) defines a novel cytochrome P450 gene family. Proc. Natl. Acad. Sci. USA. 83:42434247.

8. Solish, S. B., M. A. Goldsmith, R. Voutilainen, and W. L. Miller. 1989. Molecular characterization of a Leydig cell tumor presenting as congenital adrenal hyperplasia. J. Clin. Endocrinol. Metab. In press.

9. Tukey, R. H., S. Okino, H. Barnes, K. J. Griffin, and E. F. Johnson. 1985. Multiple gene-like sequences related to the rabbit hepatic progesterone 21-hydroxylase cytochrome P-450. J. Biol. Chem. 260:13347-13354.

10. Voutilainen, R., and W. L. Miller. 1986. Developmental expression of genes for the steroidogenic enzymes P450scc (20,22 desmolase), P450c21 (17 $\alpha$-hydroxylase/17,20 lyase), and P450c21 (21-hydroxylase) in the human fetus. J. Clin. Endocrinol. Metab. 63:11451150 .

11. Winkel, C. A., M. L. Casey, R. J. Worley, J. D. Madden, and P. C. MacDonald. 1983. Extraadrenal steroid 21-hydroxylase activity in a woman with congenital adrenal hyperplasia due to steroid 21-hydroxylase deficiency. J. Clin. Endocrinol. Metab. 56:104-107.

12. Casey, M. L., C. A. Winkel, and P. C. MacDonald. 1983. Conversion of progesterone to deoxycorticosterone in the human fetus: Steroid 21-hydroxylase activity in fetal tissues. J. Steroid Biochem. 18:449-452.

13. Miller, W. L., S. Leisti, and L. K. Johnson. 1982. Synthesis of growth hormone, prolactin, and proopiomelanocortin by ovine fetal anterior and neurointermediate pituitary lobes. Endocrinology. 111:1358-1367.

14. Cathala, G., J. F. Savouret, B. Mendez, B. L. West, M. Karin, J. A. Martial, and J. D. Baxter. 1983. A method for isolation of intact, translationally active ribonucleic acid. DNA (NY). 2:329-335.

15. Matteson, K. J., J. A. Phillips III, W. L. Miller, B. Chung, P. J. Orlando, H. Frisch, A. Ferrandez, and I. M. Burr. 1987. P450XXI (steroid 21-hydroxylase) gene deletions are not found in family studies of congenital adrenal hyperplasia. Proc. Natl. Acad. Sci. USA. 84:5858-5862.

16. Mellon, S. H., and C. Vaisse. 1989. Cyclic AMP regulates 
P450scc gene expression by a cycloheximide-insensitive mechanism in cultured mouse Leydig MA-10 cells. Proc. Natl. Acad. Sci. USA. 86:7775-7779.

17. Morel, Y., J. Bristow, S. E. Gitelman, and W. L. Miller. 1989. Transcript encoded on the opposite strand of the human steroid 21-hydroxylase/complement component $\mathrm{C} 4$ gene locus. Proc. Natl. Acad. Sci. USA. 86:6582-6586.

18. Lockard, R. E., and A. Kumar. 1981. Mapping tRNA structure in solution using double-strand-specific ribonuclease $V_{1}$ from cobra venom. Nucleic Acids Res. 9:5125-5140.

19. Winkel, C. A., C. E. Wade, D. L. Danley, P. C. MacDonald, and M. L. Casey. 1983. Conversion of progesterone to deoxycorticosterone in guinea pig spleen: an animal model for the study of steroid 21-hydroxylase activity in extra-adrenal sites. J. Steroid Biochem. 19:1635-1638.

20. Picado-Leonard, J., and W. L. Miller. 1988. Homologous sequences in steroidogenic enzymes, steroid receptors, and a steroid binding protein suggest a consensus steroid binding sequence. $\mathrm{Mol}$. Endocrinol. 2:1145-1150.

21. Horner, J. M., R. L. Hintz, and J. A. Luetscher. 1979. The role of plasma renin and angiotensin in salt-losing 21-hydroxylase-deficient congenital adrenal hyperplasia. J. Clin. Endocrinol. Metab. 48:776783.

22. Stoner, E., J. DiMartino-Nardi, V. Kuhnle, L. S. Levine, S. E. Oberfield, and M. I. New. 1986. Is salt-wasting in congenital adrenal hyperplasia due to the same gene as the fasciculata defect? Clin. Endocrinol. 24:9-20. 